\title{
MEINONGIAN SEMANTICS FOR PROPOSITIONAL SEMANTIC NETWORKS
}

\author{
William J. Rapaport \\ Department of Computer Science \\ University at Bufralo \\ State University of New York \\ Buffalo, NY 14260 \\ rapaport\%buffaloecsnet-relay.
}

\begin{abstract}
This paper survevs several approaches to semanuc network seman. tics that have not presiously been treated in the fl or computational lingusstscs literature, though there is a large philo. wophica! literature invextigating them in wime detall. In particular.

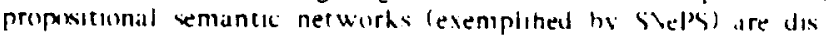
cussed. it is argued that unlv a fully incenswisal ("Veenongtan") semantics is approprlate fur them. and everal beinunglan svitems are presented.
\end{abstract}

\section{SEMANTICS OF SEMANTIC NETWORKS.}

Semantic networhs have proved io the al uselul dat. vructure for representing iniormation. l.e.. a "hnowledge" representiation svs tem. (A better terminolong is "belief", pposesentation system; cl. Rapaport and Shapiro 1984. Rapaport 198.th). The ide.1 is an ald

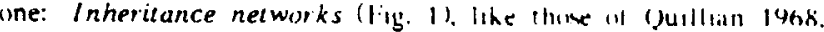

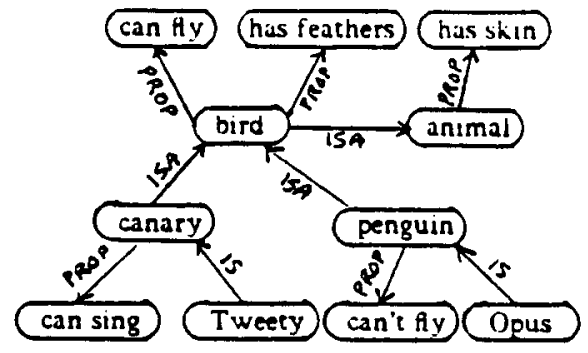

Fig. 1. An inheritance network.

Bobrow and Winograd's hikl. (1977), "r Brachmini hl.11.1. (1979), hear strong familv resemblances in "Pirphissi Pres" (lig. 2)-a mediatial device used ti lllustrate the Arstoletan theors of detinition bo species and differentia (L) hret/miann $1 \%$ hot, (h. 2; hineale and hneale 19h6: 2.32). It has heen punted out that there is nothing essentially "semantic" about semantic networks (llendrix 1979; hut of. Woods 1975. Brachman 1979). Indeed, viewed as a data structure, it is arguable that a semantic network is a language (possibiv with an associated logic or inference mechanism) for representing infirmation abrut wime domain, and, us such, is d purely syntactic entity. The have cume to he calied "semantic" primarily hecause of their uses as wave of representing the mean ings of linguistic ttems.

As a notatusnal device. a semantic netwurk can riseit be given a semantics. That is, the arcs, noxdes, and rules it a semantic network representational svitem can ix given interpretitions in terms of the entities they are used to represent. Without such a semaniss, a semantic network is an arbitrary notaturonal device lable (1) misinterpretation (ct. Woxws 1975: Brichman 1977. 1983; Holdermott 1981). The tasa of providing a semantics lor semantic networks is more akin to the task of providing a vemantics for a language than lor a logic, since in the latter case, hut not in the

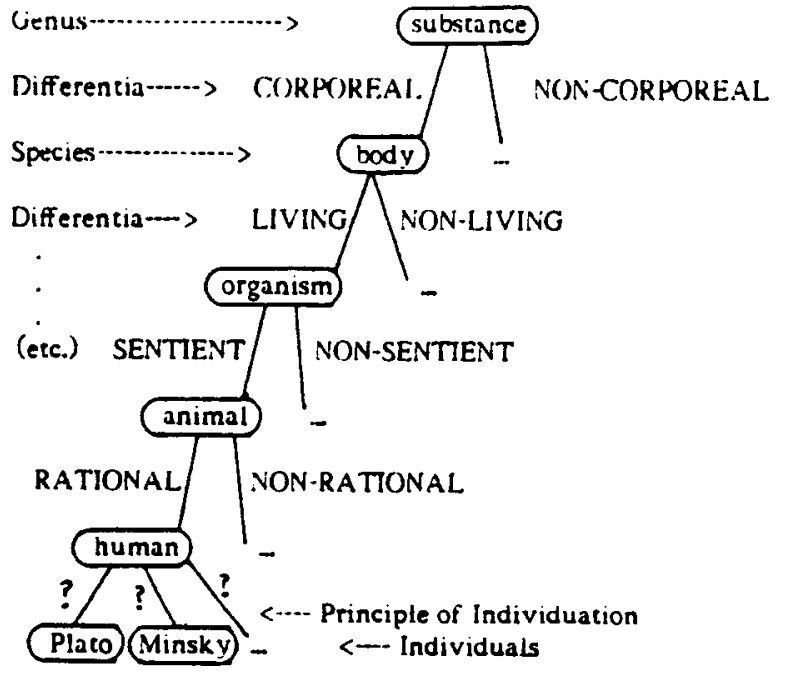

Fig. 2. Porphyry's Tree: A mediaeval inheritance network.

former. nurfons lithe ar gument batidiay must he established and con

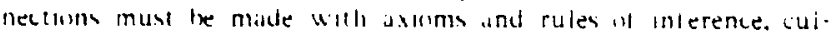
mullatung alealls in wandness and completeness theorems. But unclerlving the lagic semannsics there must be a semancuss ar the

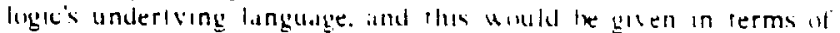

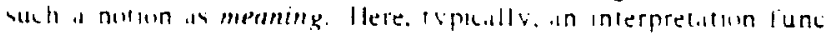

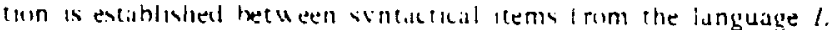
and infolengual tems I rom the "world" $W$ that the language is to descrite. This, in curn. in usualls accomplished by describing the

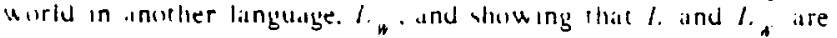

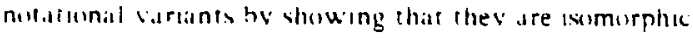

Recentlv. linguists and philosophers have argued for the impirtince "if intensional semantics tirr natural languages lat. Monlague 197.4. Parcons 19811. Kanamirt 1481). At the same time. com putaternal lingusts and other Al researchers have negun to recognice the importince ol representing intensional entitues (cf. Woxds 1975. 13rachman 1979. Mc(arthy 1979. Malda and Shapiro 1982). It xeems reasinable that a semantics for such a representatuonal sys iem should itself he an intensional semantics. In this paper. I out. line several fully intensional emancics firr incensiunal semantic netuorkis by discussing the relatons herween a semantic network "!inguage" $l$, and everal candidates for $l_{*}$. For $l ., I$ focus on Shapiro's propositional Semantic Vetwork Processing Svstem (Sivel's: Shilpirs 1979), for which Israel (1983) has offered a poxsible-worlds semantics. But possible-worlds semantics, while countenancing intensional entities. are not fully intensional, since they treat intensional entities extensionally. The $L_{w}$ s I discuss all 
have fully intensional components.

\section{SNePS.}

A SiePS semantic network (Fig. 3) is primarily a proposi-

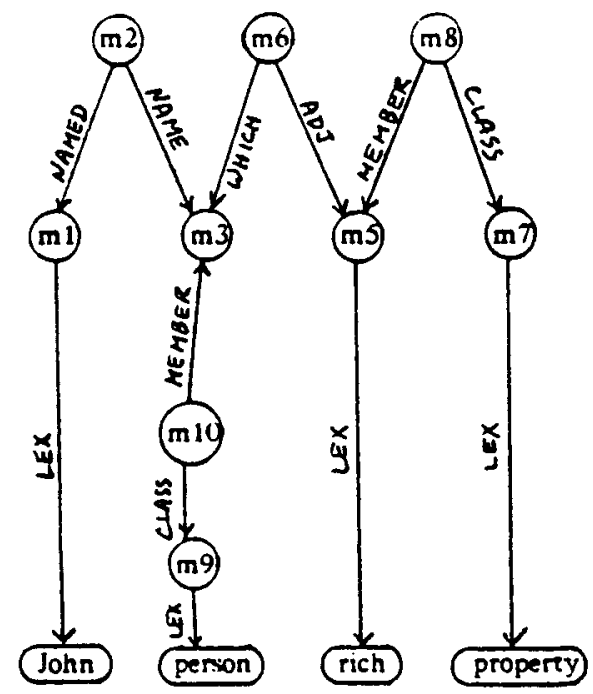

Fig. 3. A SNePS representation for 'A person named "John" has the property of being rich.'

ional network (see belou). It can, however. alsi) he ised to represent the inheritability of properties, etther hv explicit rules of by pach-based inference (Shupiro 1978). It consists of lubeled nodes and laheied. directed arcs satis ving (inter alia) the following condition (cl. Malda and Shapiro) 1982):

(S) There is a 1.1 correspondence herween noxdes and represented concepes.

A concept is anvthing about which intormation can he stored and/or transmitted" (Shapiro 1974: 174). When a semantic net work such as Siet's is used to model "the hetiet structure of a thinking. reasoning, language using being" Malda and Shapiro 1982: 296: cl. Shapiro 1971 h: 51.31. the concepts are the obects of mental (1.e. intentunal) acts wuh as thinking, treliev.ng. Wishing. etc. Such ohecis are inrensicinal ict. Kapuport 1978).

It follows trim (s) that the arcs do not represent concepts. Kather. thev repreent hinars, structural relacions between concepts. If it is desired ti talh aboul certain relations between concepts, then those relations must he represented by nodes. since they have inen becisme objects of thought. te. concepts. In terms of Ouine's dictum that "to be is to be the value of a [tound] variable" (Quine 1980): 15: cf. Shapirn 1971a: 79-80), nodes represent such values, arts do no:. That is. E!ven a domain of discourse-including tems, $n$ arv relations among them, ard proposituns-\$it's nowes wouid be used to represent all members of the domain. The arcs are used to structure the items, relatuns, and propusitums the comann into (other) propisituns. As an analogy, sleps arcs are to

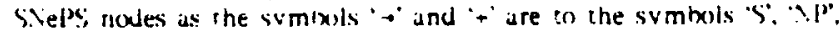

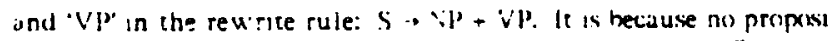
tiuns are represented hv arcs that Sileps is a "propessitional" semanuc network (ct. Waidis and Shapiro 1982: 292).

When a semantic network such as Silets is usect to model a mind, the nodes represent only intensional items (Maida and Shapiro 1982: cf. Kapaport 1978). Similarly, if such a network were to be used is a notation for a fully intensional naturallunguage semantics (such as the semantics presented in Rapaport
1981), the nodes would represent inly intensional ttems. Thus, a semantics for such a network ought itself to be fully intensional.

There are two parrs ol tvpes of nodes in S.Veps: constant and varable nodes, and atomic (or individual) and molecular (or propositional) nodes. (Nolecular individual nodes are currently heing implemented: see Sect. 7. 8. For a discussion of the semantics of variable noxles, see Shapiro 1985.1 lixcent for a few pre-detined arcs for use bv an inference package, all arc labets are chosen bo the user: such tabels are completelv arhitrary (alhett of ten mnemonic) and depend in the dimain teing represented. The "meanings" of the labels are provided (hy the userl only hy means of explicit rule nodes, which dllow the retrieval in construction (by inierencing! of propasitunal noxdes.

\section{ISRAEL'S POSSIBLE-WORLDS SEMANTICS FOR SNEPS.}

David lsrael's semantics fur Siel's assumes "the general framework of Kriphe-Viontague style model thenretic accounts" (Israel 198.3: 3), presumably hecause he tahes it as "quite clear that

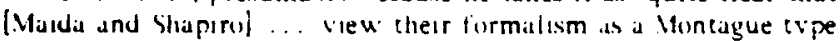
ivpe theoretic, intensional svistem" (Israel 198.3: 2). He introduces

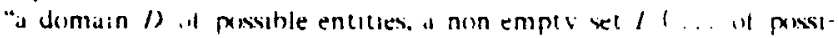
ble $u$ orlds), and ... a distingushed element $w$ of $I$ in represent the real world" (lsritel 148.3: 3). In individual comcept is a lunc

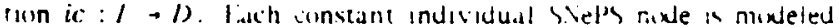
hy an ic: vartable individual nixles are handled hv "dssignments relative "1) such a mixdel". Ilouever, predicates- which, the reader should recall, are also represented in Steps ho constant indisidual noxles-are modelled as l unchons "I rom I intw the pouer set it the

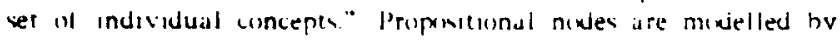

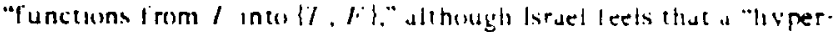
intenswonal" ligic wald the needed in irder th handle propisitlinal attitudes.

Israet has ditheulte interpreung WI:MIBI:K. (1.ASS, and ISA

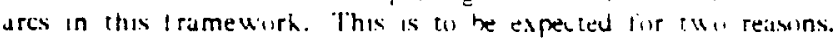
first. II is arguabls a mistake to interpret them ( rather than guing rules for them). since thev are arcs, hence arhicrarv and nonconceptual. Seciond, a pussible worlds semantics is not the best approach (nor is it "clear" that this is what Marda and Shapiro had in mind-indeed. thev explicitly reect it: cf. Malda and Shapiro 1982: 247). Israet himself hunts at the inappropriateness of this upprosich:

If one is fixusing un propasitional attitudels?... it wan weem like a Waste of time to incroduce moxlet-theoretic ac counts ut intensionality at all. Thus the alr of desperatun aixut the foregoing attempt ... . (Israel 198.3: 5.)

Moreover-and signiticantlv-a possible-worids approach is misguided $\|$, ine wants to be able th represent impessible uhkts, wh une should want to it one is doing natural language semantics (Rapa. port 1978, 1981: Routlev 1979). A luliv intensional semiantic net work demands a fully intensional semantics. The man rival to Inntague-stvle, posible-worlds semantics los well as to its cluse

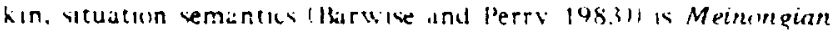
semantic's

\section{MEINONG'S THEORY OF OBJECTS.}

Alexius Meinong's $(19(1) 4)$ theory of the shects of pxicholog1cal acts is a more approprate ioundation for a semantics of promositoonal semantic neiworks as well as forr a natural-language seman. tacs. In hriel. Meinung's theorv consists of the following theses (cf. Rapaport 1976, 1978):

(M1) Thesis of Intentionality: livery mental act (e.g., thinking. believing, judging, etc.) is "directed" towards an "object".

There are two kinds of Meinongian objects: (1) objecta. the individual-like ohjects of such a mental act as thinking-of, and (2) 
objectives, the proposition-like objects of such mental acts as believing(-that) or knowing(-that). E.g., the object of mv act of thinking of a unicorn is: a unicorn: the obpect of $\mathrm{mv}$ act of believing that the liarth is Hat is: the Barth is flat.

(M2) Vot every object of thought exists (technically, "has being").

(M3) It is not self -contradictory to deny. nor tautologous to affirm. existence of an object of thought.

(M4) Thesis of Aussersein: All objects of thought are ausserseiend ("beyond being and non-being").

For present purposes, Aussersein is most easily explicated as a domain of quantification for non-existentially-lisaded quantitiers. required by $(.12)$ and $(.143)$.

(MS) livery object of thought has properties (technically. "Sosein").

(M6) Principle of Independence: (112) and (MS) are not inconsistent. (lior more dixcussion. ct. Ralpapurt 1984c.)

Corollary: liven abrects of thought that do not exist have properties.

(117) Principle of linedom of tssumprion:

(d) livery wet of propertes (Sissein) corresponds (o) an ahpect of thought.

(b) Everv oblect of thought ian le thought of (relatise in certan "pertiormance" limutations).

(V18) Sime ohfects of thought are incimpiete fi.e. undetermuned with respect to sime properties).

(\$19) The meaning of everv sentence and mon phrave is an whect (:) thoughte.

It should be obvious that there is a close relationship between Veinong's theory and a fullv intensional vemantic network lake Sivel's. Sivel's itseif is much the Ausser sein: Shapiro (personal communication) has sald that all naxes are implicatly in the net work all the elme. In particular. a Sivel's base (1.e., atomic constant) noxde represents in objectum, and a sivel's propasicional node represents an ishectuve. Thus, when Siliefs is used ats in mondel of a mind, propositional nodes represent the uhjectives of hetiels lat Vaada and Shapiro 1982. Rapapore and Shapiro 1984. Rapaport 198 thi; and when Sl:prs is used in a natural language processing sistem (ct. Shapiro 1982. Rapaport and Shapiro 1984), individual nodes represent the meanings of noun phrases and verh phrases. and propositional noxles represent the meanings of sentences.

Meinong's theorv was attacked by lertrand Russell on grrunds of inconsistencv: (1) fccording in Meinong, the round square is hoth round and square (Indeed. this is a tautolingv): vet. accirding to kussell, if it is round. then it is not square. (2) Similarls. the existing gellden mountain must hase all three of its defining properses: heing a muntain. heing imiden. and existing hut. as kussell noted, 1: doesn l exist. If 1. Rapaport 1976. 1978 Iur ret erences.)

There have ben several lurmaltations of Vesnongan theortes in recent phiosophical literature. each of which overcomes these problems. In subsequent sections. I briefly descrite three of these and show their relationships to SNePS. (()thers, not described r.ere, include Koutlev 1979-cl. Rapaport 1984j-and Zalta 1983.)

\section{RAPAPORT'S THEORY.}

(In $\mathrm{my}$ own reconstruction of Meinong's theory (Rapaport 1976. 1978-which beurs a conncidental resemblance to McCarthy 1979), there are two types of (ubjects: $M$-objects (i.e., the objects of thought, which are intensional) and actual objects (which are extensional). There are two modes of predication of properties to these: M-objects are constituted bv properties, and both $\mathbf{M -}$ and actual objects can exemplify properties. For instance, the pen with which I wrote the manuscript of this paper is an actual ohject that exemplifies the property of being while. Right now, when I think about that pen, the ubject of my thought is an M-ubject that is constituted (in part) by that property. The M-object Jan's pen can be represented as: <beionging to Jan, being a pen> (or, for short, as: $\checkmark, P>)$. Being a pen is also a constituent of this $M$-object: $P$ o $\langle J, P>$; and 'Jan's pen is a pen' is true in virtue of this objective. In uddition. $\langle J, P>$ exemplifies (ex) the property of being constitused by two properties. There might be an actual object, say, $a$, corresponding $(0<J .|l\rangle$, that exemplifies the propertv of being a pen (ar ex $P$ ) as well as (sav) the property of being (finches long.

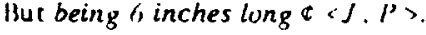

The W-obrect the round square, a $R . S$; is cunstituted bv preusely two properties: heing round $(R)$ and heing square $(S)$ : "The round square is round" is true in virtue of thas, and "The round square is not square' is false in virtue of it. But $\langle R$. $S$ ' $\rangle$ exemplities neither of those properties. and "The round syuare is not syuare' is true in virtue of that. l.e., 'is' is ambiguius.

An Mihnect " exists ift there an an alual whect if that is

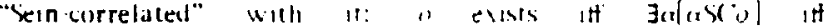

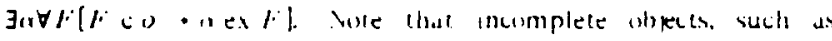
'J, P. can evist. lligweser. the Whinget the existing golden mountain. $I S,(;, M)$ has the property of existing (because

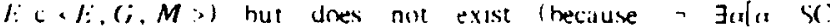
$\because A, C, M>l$ as an empirical lact).

The intensional fragment of thas theors can be used to provide a semantics for biveps in much the sime waly hat it can been used to provide a semantiss lor natural languige (Rapaport 1981). Siel'S base noder cin be lathen (o reprevent 11 uhectia and propertses:

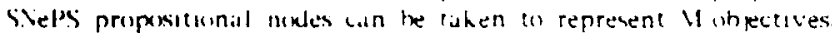

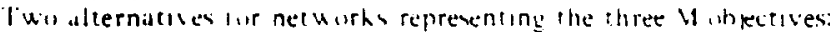

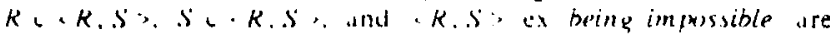

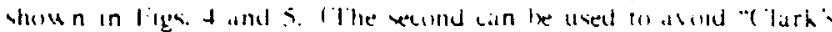

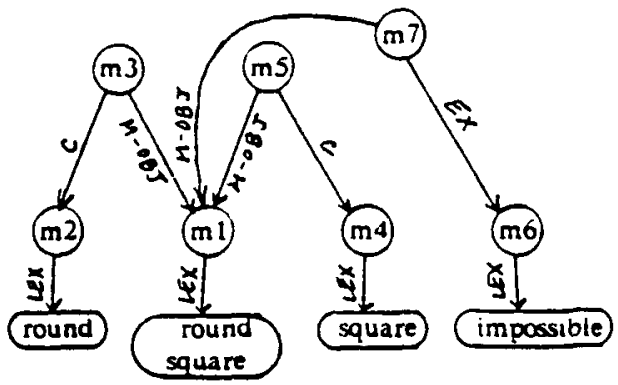

Fig. 4. A SNePS representation of

The round square is round'. 'The round square is square', and 'The round square is impossible' on Rapaport's theory.

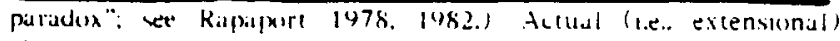
ahpects. !wwever, should now be represented (a). Watdo and Shapiro 1982: 296 98). To the extent (o) which such shkcts are exsental to this Vernonglan theorv. the present theory is perhaps an inapproprtate one. IA similar remark hoids, of course. for Mol arthy 1979.)

\section{PARSONS'S THEORY.}

Terence Parsons's theorv of nonexistent objects (1980; cf. Rapaport 1976, 1978, 1985) recognizes onlv one tvpe of objectintensional ones-und only one mode of predication. But it has two 


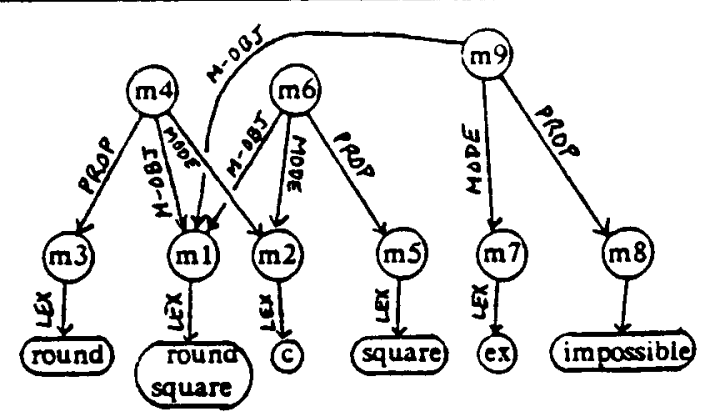

Fig. 5. An alternative SNePS representation of 'The round square is round'. 'The round square is square', and 'The round square is impossible' on Rapaport's theory.

tvpes of properties: nucleat and extranuclear. The former includes all "ordinary" properties such as: being red, heing round. etc.; the latter includes such properties as: existing. heing impossible. etc. But the distinction is hlurry, since lor eash extranuclear property. there is a corresponding nuclear ane. lior everv set of nuclear pro pertles, there is a unuque whect that has unly those properties. lixistung whects must be complete (and. at curse. cunsistent). though not all such whects exist. For instance. the Morning Star and the livening Star don't exist fil these are taken to consist. roughiv, of unly two properties each). The lound syuare. of course.

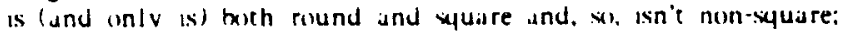
though it is, for that reasin. impissible. hence not real. As for the extsting golden mountain, exiscence is extranuclear, w the set is these three properties disesn't hate a corresponding whect. There is, houever. " watered Jou n". nuclear verswon of existence, and there is un existing golden mountatn that has that propertv; hut it diesn't have the extranuclear propertv at existence, and. so it doesn't exist.

Parsunsis theorv could provide a emantics lor Sivels, though the use of two types of properties places restrictions on the possible uses of SiNePS. (On the ocher hand. S.iel'S could be used to represent Parsons's theory (though a device would be needed for marking the distinction between nuclear and extranuilear properties) and, hence. tongether with parsins's natural language wemantics, to provide a rait for computatuonal linguistics. Hig. h suggests how this mighe he done.

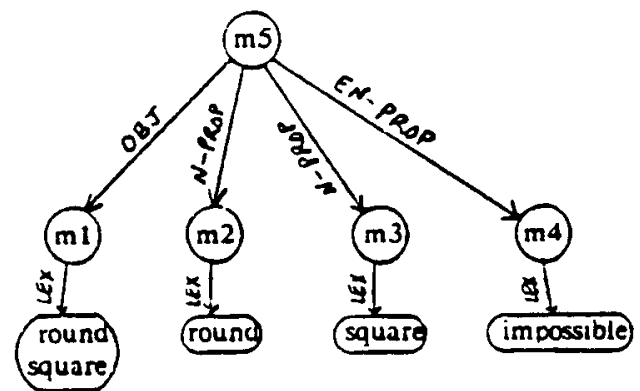

Fig. 6. A SNePS representation of The round square is round, square, and impossible' on Parsons's theory.

\section{CASTAÑEDA'S THEORY.}

Hector-Vari Casianeda's theory of "guises" (1972. 1975a-c. $1977,1979,1980)$ is a hetter andidate. It is a fully intensional theory with one type of object: guises (intensional items corresponding to sets if properties). and one tvpe of property. More precisely, there are properties (e.g., being round, being square, being blue, ... ), sets of these (called guise cores: e.g., lbeing round, being squarel). and an ontic counterpart, $c$, of the detinite-description operator, which is used to form guises: e.g., clbeing round. being squaref is the round square. (julses can be understodd. roughlv, as things-under-d-description, as "facets" of (physical and nonphysical) objects, as "roles" that objects play, or, in general, as ohjects of thought.

Guise theory has two modes of predication: internal and external. In general, the guise $c\{\ldots l \ldots\}$ is-internally $r$. F...., the guise (named by) the round square is-internally onlv round and square. The two guises the tallest mountain and $M t$. liverest are related by an external mode of predication called consubstantiation $\left(C^{*}\right)$. (onsubstantiation is an equivalence relution that is used in the analyses of (1) external predication, (2) co-reference. and (3) existence: l.et $a=c\{\ldots l \ldots\}$ he is guise and let

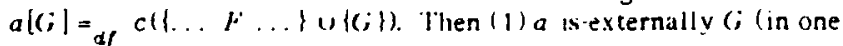
sense $)$ if $C^{*}(a, a[G])$. For instance. 'the Morning Star is a planet' is true because $C^{*}(c\{M . S\}, c\{M, S . P\})$, i.e.. the Morning Star and the Morning Star that is a planet are cunsubstantlated. (2) (juise a "is the sime as" gulse $b$ if and unlv if ("ab. For instance, "the Mirning bear is the ame as the livening ftar is true hecause

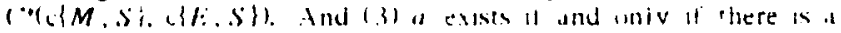
guse $b$ such that $(" a b$

Another evternal mide of predication is cissociution $(r)$. This is also an equivalence relatwon. hat one that holus between gulses that a mind has "put together". 1.e. hetween guses in a "heliet space". Jor instance, (: "*llamlet. the Prince of lenmark).

(" and (:" currexpend almust exactly $"$ " the use if the

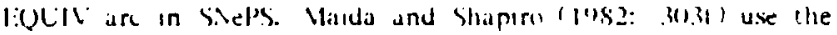
f:QLIN case trame to reprevent to reterence 1 which is what $(\cdot$ is).

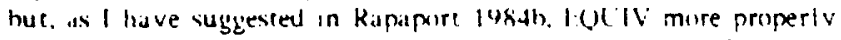

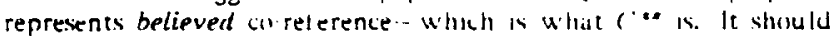

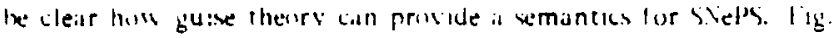
7 suggests b:ou thas moght be done. bime prohlems remann. bou

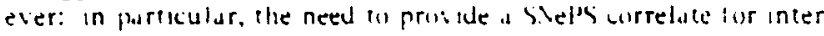
nal preduatum and the reyurement il esplicating external predica

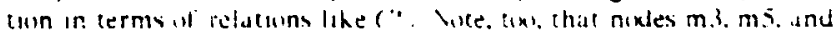

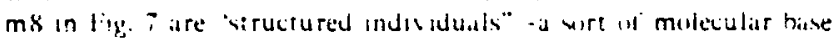
ninde.

\section{CONCLUSION.}

It is possible to provide \& tully intensional. non possible worlds semantics for Sivel's and similar semartic necworh formal isms. The most straghttorward wat is to use Veinong's theort of whects, thagh this theorr has the disadvantage ol not being firmalied. There are several extant formal Mesnonglan theorles that can the used, though eah hats certain disidvantages or prohlems. Two lines of revearch are currentls being investlgated: (1) Tithe Silefos as is, and provide a new. lormal besnonglan theorv lor its semantio diundation. This has not been discussed here, hut the 'way (i) do this bhinuld be clear from the possibilities examined above. Vv iun theors (strinped of its extensional l rayment) of a

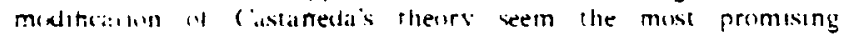
appromiles. !2: Vhadily shefs $\$$ that une if the extant lormal

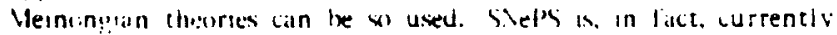
theing miditied by the Siel's Research lirmp-lar independent

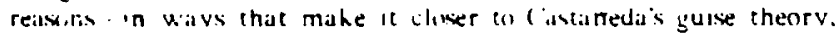
hv : he intrixduction of structured individuals-- "hase nowdes" with dexcending arcs for indicating their "internal st ructure".

\section{ACKNOWLEDGMENTS.}

This research was supported in part by SLiY Buffalo Research Devejupment Fund grant $=15(1)-9216-5$. I am grateful to Stuart C. Shapiro, Hector-Neri Castaneda, and the members of the SNePS Research Group for comments and discussion. 


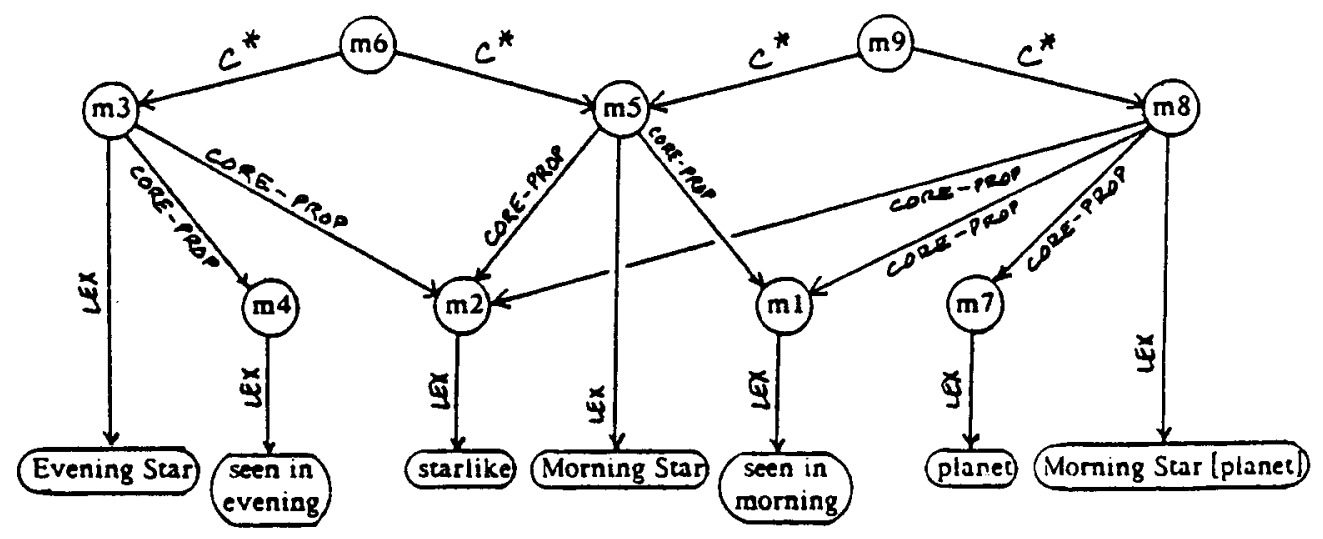

Fig. 7. A SNePS representation of 'The Morning Star is the Evening Star' (m6) and 'The Morning Star is a planet' (m9) on Castaneda's theory.

\section{REFERENCES}

Burwise. Jon, and lohn Perrv. Situations and Altiudes (f ambridge. Wass.: MIT Press, 148.3).

Bhobrow. Daniel (i.. and Terrv Winograd, "An (Nersiew ot hKI.. a hnowledge Representation language." ('ugnitive sicience $1(1977) 3 \cdot 46$.

Brachman. Ronald J., "What's in a Concept: Siructural foundatuns tor Eemantic Vetworks," Int. J. Man-Machine Situdies $9(1977) 127 \cdot 52$.

"()n the lipsstemological Status of Semantic Vetworks," in findler 1979: 3-50.

"What IS-A Is and lsn't: An Analvsis of liasunums links in Semantic letworks," Compuler $16(1$ kt. 148.3)30).3h.

Castarneda, llector-Verı, "Thinking and the Structure of the World" (1972). Philosophia 4(1974).3-4): reprinted in 1974 in (itica 6(1972)4.3-8h.

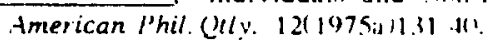
$5(1975 h) 121.50$.

Thinking and Doing (Ixordreuht: 1). Ketdel. $19750)$.

"Perception. Beliet, and the Structure of Phvsical 1)bects and Consciousness." Synthese 35(1977)285-351.

"Fiction and Reality: Their Rasic Connections," Poetica 8(1979)31-62.

"Reference. Realitv, and Perceptual lields." proc. and Addresses American Phil. Assoc. $53(1980) 76.3-82.3$.

linciler, $v$. V. (ed.), Associative Netwolks (New Yorh: Academic Press, 19791.

llendrix, Ciarv (;., "lincoding knowledge in Pibtituned betworks," in findler 197\%: $\$ 192$

Israet, l Mavid J., "Interpreting letwork formalisms," in V. Cercune (ed.), (omputational i.inguistic.s (1)xlort: Pergamon Press. 1983): 113

kneale. Willam, and Martha knealt, The bevelopment of Iagic (1)xford: Clarendon P'ress, 3rd prinung. 196h).

hretonann, Vormun (trans. and ed.). William of therword's "/ huro

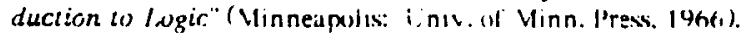

Warda, Anthonv S., and Stuart 1. Shapiro, "Intensonnal Conceprs in Propasitionat Ėmantic Networks." (iegnitive sicience 6(1982)291-3.30.

Ved arthv, 1.. "lirst (1)der Theories of Individual Concents und Pro. prisitions," in 1. 1:. Hayes. 1). Sichie. and 1.. Mikulich (eds.). Machine Intelligence Wr:hichester. Iing.: I:Ilis IJorwoxd. 1979).
129) 17.

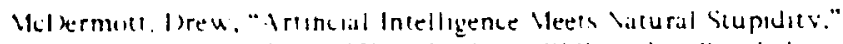
in 1. Haugetand (ed.). Mind losign: l'hilusenphy. Psychology.

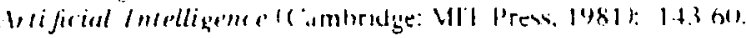

Veinung. Alexus. "ither (iegenstandstheurte" (gyr(1), in R. Haller (ed.). Alexius Meinong Gesamlausgabe Vol. Il ((iral. Austrat thademixhe l)ruch u. Verlagkinstitt, 1971): 481 -5.35. linglish

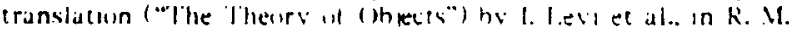
("hisholn led.), Keralism and the lsackground of phenomenology (Nen Virh: firee Press, 14hol): 7h-117.

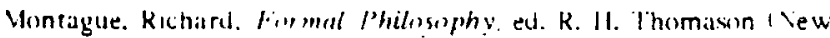
llaven: iale ( nus. l'ress, 1974)

Parsins. Terence. Nomexistent abjerts (hew llaten: Vale Lnav. Press. 198(1).

Quillian, Wt. Kows, "Semantic Memorv." in W. Minskv (ed.). Semantic In formation Processing ("umbridge: WI'I Press, 1968): 227-66.

Quine. Willard Vin (brman. "In What There ks," in Fom a logical Point of liew (c umbridge: llarvard (nIc. l'ress. Ind ed.. 1980): 1.19.

Rapaport. Willam I., Intentionality and the structure of lixistence. Ph.l). diss.. Indiana ( nivi. 197h.

"Meinonglan Theories and a Russeilian Paradox." Noüs 12(1978)15.3 S1) erratu. Noüs 1.319741125.

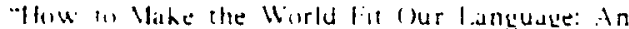

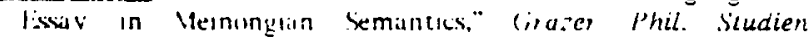
$14198111-21$.

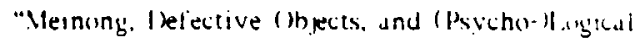
Paradox." (irazer Phil. Studien 18(1982)17-39.

Critical votice of Koutley 1979, Phil. and Phenomenological Research $+4(1984 a) 539-52$.

. "Weliet Representation and (Juasi-Indicators," Tech.

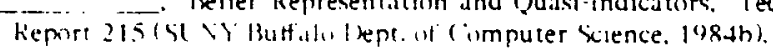

kevele il I.umixert's Meinong and the Principie

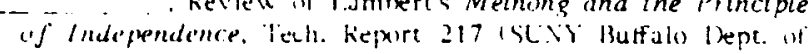

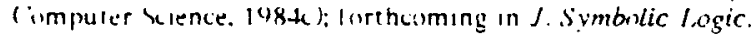

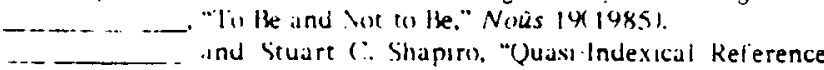
in Propusitonal temantic Vecworks." proc. loth Int. Conf.

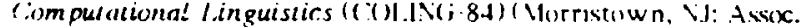

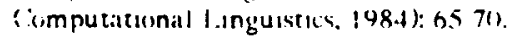

Koutley, Richard. Itxoloring Meinong's Jungle and Beyond (C:an. berra: Australian ivacl. Lniv.. Research Sich(x)l of Sixial Sictences, Dept. of Philoxuph v. 1479).

Shapiro, Stuart (: The MIND system: A Data Siructure for Simantic Information Processing. Report R-837-PR (Sinta Monicia: Rand (orporatıon. 1971). 
“A Vet Structure for Semantic Information Storage.

Deduction and Retrieval," Proc. /JC.t/ 2(1971h)512-2.3.

"Path-Pased and Vode-Based Inference in Semantic Vetworks," in 1). Waltz. (ed.). Theoretical /ssues in Natural Language Processing 2(1978)219-25.

"The SNePS Semantic Vetwork Processing System," in Findler 1979: 179-203.

"Generalized Augmented Transition Network Grammars For Generation From Semantic Networks," American J. Computational linguistics 8(1982)12-25.

"Symmetric Relations, Intensional Individuals, and Variable Binding." (lorthcoming, 1985).

Woxds, William A.. "What's in a l.ink: The Semantics of Semantic Verworks." in I). (i. Buhrow und A. M. Collins (eds.), Representation and (/nderstanding (New Yurk: Academic Press, 1975): .35-79.

Zalta. liduard, fbst act ()bjects (I hirdrecht: 1). Retdel. 198.3). 